\title{
THE EFFECT OF FUNDING AND RISK ON FINANCING DECISION Empirical Study of Islamic Banks in Indonesia
}

\author{
Sutrisno \\ Universitas Islam Indonesia Yogyakarta \\ Sutrisno_Uii@Yaboo.Com
}

\begin{abstract}
The purpose of this study was to analyze the effect of funding decisions and risk to financing decisions on Islamic banking in Indonesia. Funding decisions consists of variable wadia demand deposits (GWD), mudaraba saving deposit (TAB), and mudaraba time deposits (DEP). Risk is proxied by capital risk (CAR), liquidity risk (RR and FDR), and financing risk $(N P F)$. While the financing decisions consists of murababa financing, mudaraba financing, and Musharaka financing. Samples were taken from all Islamic banks operating in Indonesia by 11 Islamic banks, and quarterly data using multiple regression analysis. The results showed that DEP and TAB significant and positive impact on all of financing, while GWD significant and positive impact on murabahafinancing is however negatively affect to mudaraba and musharaka financing. CAR and RR a significant and negative effect on all of financing. NPF non significant effect on all financing decisions, while FDR significant and negative effect on mudaraba and musharaka financing, but no significant effect on murabaha financing.
\end{abstract}

Keywords: Murabaha, Mudaraba, Musharaka, Wadia

\begin{abstract}
Abstrak
Tujuan penelitian ini adalab untuk menganalisis pengarub kebijakan pendanaan dan risiko terbadap kebijakan pembiayaan pada perbankan syariah di Indonesia. Kebijakan pendanaan terdiri dari variabel giro wadiah (GWD), tabungan mudharabah (TAB), dan deposito mudharabah (DEP). Kebijakan risiko diproksikan dengan risiko permodalan (CAR), risiko liukiditas (RR dan FDR) dan risiko pembiayaan (NPF). Kebijakan pembiayaan diukur dengan pembiayaan murabahah, pembiayaan mudharabah dan pembiayaan musyarakah. Sampel penelitian diambil dari semua bank syariah yang beroperasi di Indonesia sebanyak 11 bank umum syariah, dengan data kwartalan kemudian diuji menggunakan alat uji regresi berganda. Hasil penelitian menunjukkan bahwa deposito mudharabah (DEP) dan tabungan mudharabah (TAB) secara signifikan dan positif berpengarub terhadap semua variabel pembiayaan, sedangkan giro wadiah (GWD) signifikan dan positif berpengaruh terhadap pembiayaan murabahah tetapi berpengarub negatif terhadap pembiayaan musyarakah dan mudharabah. CAR dan RR berpengarub signifikan dan negatif terhadap semua pembiayaan. NPF pengarubnya tidak signifikan terbadap semua pembiayaan Sementara FDR pengarubnya signifikan dan negatif terhadap pembiayaan mudharabah dan musyarakah tetapi tidak signifikan terhadap pembiayaan murabahah.
\end{abstract}

Kata Kunci: Murabahah, Mudharabah, Musyarakah, Wadiah

Permalink/DOI: http://dx.doi.org/10.18326/infsl3.v10i1.115-134 


\section{Introduction}

Banking law No. 7 years 1992 mentions that the function of a bank is to be a financial intermediary of a society that excess funds (surplus units) to people who lack the funds (fund deficit). In conventional banking, bank profits derived from the difference between interest rates on loans and interest rates on deposits (Siamat, 2005). In Islamic banking, because the element of interest rates is prohibited, then the third party fund raised will be distributed in various forms. According to Antonio (2001), the distribution of funds to public is divided into some concepts, the profit margin concept, profit sharing concept, the concept of rent, as well as a social concept. Distribution of funds in thethe concept of margin is called murabaha financing, with the concept of profit sharing in the form of mudaraba financing and Musharaka financing, based on the concept of rent called ijarah financing, and based on the concept of social form of qard financing.

Sources of funds banks largely derived from the third party fund in the form of demand deposit, saving deposit, and time deposits. In Islamic banking, the third party funds is compensated in accordance with the savings contract. Savings contract could use public funds entrusted or wadia concept and profit sharing contract or mudaraba. Demand deposits (giro) are generally based on wadiacontract. The savings can be taken at any time and because the concept is deposited, the bank is not obliged to provide compensation, but if the bank gain will usually give a bonus to the holders of girowadia depends on the banks (Mohammad, 2011). While the savings can use wadia and mudaraba contract, while deposits are generally based on the concept of mudaraba. The more the amount of public funds, the more opportunities will be provides to expand financing, meaning that the greater the greater public funds peluangan financing provided. Pratin and Akhyar (2005) found a positive and significant effect of third party funds with financing provided. Arianti and Muharram (2012) also find thirdparty funds affect the financing, while Satria and Subegti (2010) who conducted research on conventional commercial banks do not find a significant influence of third party funds to loans. 
The amount of financing provided will also be influenced by various risks faced by Islamic banks. There are several risks faced by banks, which are capital risk, financing risk, and liquidity risk. Banks capital is measured by the ratio of capital adequacy or capital adequacy ratio (CAR). The higher the bank's capital adequacy ratio indicates the lesser efficient use of capital, therefore it is reducing the opportunities for financing. Liquidity risk in the form of the provision of funds by the bank is if the people take their funds at any time, so that the bank must provide the specified minimum waji checking at least 5\%. Liquidity also involves a commitment to provide financing bank as measured by the financing to deposit ratio (FDR). While the financing risk is measured by financing problems or non-performing financing (NPF). Satrio and Subegti (2010) found a significant effect on CAR loans. Arianti and Muharram (2012) and Pratin and Akhyar (2005) used the CAR and the NPF as variables affecting Islamic bank financing.

\section{Theoritical Review}

\section{Islamic banks}

Islamic banking has been long awaited by the Muslim community, the end of 1992 were marked by the establishment of Bank Muamalat Indonesia (BMI)). The main difference between Islamic banks with conventional banks interest is the use of the instrument. In conventional banks, in operation both in providing compensation to depositors and services charged to the borrower interest based. In Islamic banks, interest instruments is not permitted, because the interest in the category of 'riba' which is forbidden in Islam. According to Undang-Undang RI No. 10 of 1998 on amendments to Banking Law No. 71992 in article 1, paragraph 1 refers to the sense of the bank. 'Bank is an entity that collects funds from the public in the form of savings and channel them to the public in the form of loans or other forms in order to improve the standard of living of the people'. Understanding confirms that the main function of the bank is a financial intermediary that is collecting funds from the public and distributing them to the public in the form of credit or other form. 


\section{Principles and Objective}

Based on the operating principle of Islamic banks based on Article 2 of Law No. 21, 2008, stated that Islamic banking in conducting its business activities based on Islamic principles, economic democracy, and the principle of prudence. Further related to the goal of national development bank in order to improve justice, solidarity and equitable welfare.

According to Hidayat (2008), as a financial system based on Islamic law, then he said, the direction and objectives of the establishment of Islamic finance must necessarily to realize the objectives of Shariah (maqasid al-Sharia). In general, the purpose of Sharia categorized to education (tarbiyah), justice (is), and the welfare of the people (maslahatul ammah). Here is the goal of Islamic banks by Sumitro (2002):

a. To direct the people's economic activity air-Muamalat in Islamic Muamalat in particular relating to banking to avoid the practice of usury or types of business / other trades containing gharar (hoax), where these types of businesses besides forbidden in Islam, also has a negative impact on the economic life of the people.

b. To create a justice in the economic field with the leveling of income through investment activities, in order to avoid huge gaps between the owners of capital to those who need funds.

c. To improve the quality of life of the people by opening a chance to make a bigger especially the poor, which is directed to a productive business activities, towards the creation of independence effort

d. To improve the quality of life of the people by opening a chance to make a bigger especially the poor, are directed to productive business activity, leading to the creation of business independence.

e. To maintain economic and monetary stability. With the activity of Islamic banks will be able to avoid overheating of the economy due to inflation, to avoid unfair competition between financial institutions. 


\section{Function of Islamic Bank}

According to Yahya et al (2009) explains that in some of the literature of Islamic banking, Islamic banks with a variety of schemes owned transactions in non-usury scheme has at least four functions, namely:

a. Investment manager function

This function can be seen in terms of fund-raising by Islamic banks, particularly mudaraba fund. With this function Islamic bank acts as investment manager of the fund owner (shabibul maal) in the case of these funds should be channeled to the productive distribution, so that the funds raised can generate profits to be divided generate between Islamic banks and the owner of the funds.

b. Investors function

In disbursement of funds, Islamic banks functioning as investor (owner of the funds). As an investor, investments that were made in productive sectors with minimal risk and do not violate the provisions of Islamic banks. Additionally, the invested funds of Islamic banks should use investment tool in accordance with sharia.

c. Social function

The social function of Islamic banks is something that is inherent in Islamic banks such as the implementation of corporate social responsibility.

d. financial services function

The function of financial services that are run by Islamic banks are not different from conventional banks, such as providing clearing services, transfer, collections, payroll, letters of credit, letters of guarantee, etc.

\section{Funding products}

Basically, bank funds come from three sources, those are from the deposit called the owner's own capital, from banks or other institutions, and it mostly came from the public. Compensation for 
the source of funds from the public are not permitted to use interest as the instrument but rather use the agreement, as follows:

a. Wadia contract, the contract public savings which uses the concept of surrogate (wadia). With this wadia concept, customers entrust their funds without expecting any reward (Sudarsono, 2003). Normally banks provide bonuses that are not determined in advance as compensation. The application of this wadia contract are more often in the form of giro, and some small savings.

b. Mudaraba contract, the public savings in the bank for which the contract is based on the concept of profit sharing. Customer save funds and those funds can be used by banks for generating profit. If the bank gets profits, customers will receive the profits of a predetermined ratio at the beginning (Mohammad, 2011). The application of this concept to the results of the banks in the form of mudaraba savings and mudaraba deposits.

\section{Financing products}

The provision of loan to customers in the Islamic banking is called financing, while in conventional banking is called credit. Islamic banks can use some of the concepts in providing financing, among others, the concept of profit margin (trading), the concept of profit sharing, the concept of rent, and social concepts. In this study, only two concepts discussed the concept of margin and profit sharing with its products:

a. Murabaha financing. Murabaha financing uses the concept of profit margin, where customers who need financing for an item to be bought to come to the bank to negotiate a profit margin. After the purchase contract deal is done, then the bank buys the goods which the bank purchases represent to customers. Items purchased directly shipped to the customer and the customer will pay the purchase price of the goods plus profits by way of direct payments behind or paid in installments (Sudarsono, 2003). 
b. Mudaraba financing. Mudharaba financing is based on profitloss sharing, the first financing done is profit sharing agreement, after the bank giving fund to all project funding needs while project management is done by the customer entirely. Profits earned will be distributed to banks and customers in accordance with the profit sharing ratio agreed upon at the beginning. Bank other than in accordance with the profit ratio is also entitled to a refund of all the capital that had been deposited in the project (Sudarsono, 2003).

c. Musharaka financing.

This financing uses the concept of profit-loss sharing, in which the bank put up the money as capital into a business project, and bank funds put together with customer funds into capital projects. Customers and the banks manage business projects in order to make a profit. Profits earned will be distributed to banks and customers in accordance with the agreed ratio, which generally correspond to the portion of the portion of capital deposited by each party (Sudarsono, 2003)

\section{Banking risk}

Banks are highly regulated which company operations regulated by the bank authorities, therefore the management of banks should be careful in doing business. Bank Indonesia through circulars SE No. 5/21 / DPNP / 2003 on the application of risk management and updated with circulars SE No. 13/23 / DNDP in 2011, the process of risk management is done on credit risk, capital risk, liquidity risk, operational risk, market risk, legal risk, reputation risk and strategic risk and compliance risk. In this research only involves some risk.

a. Capital risk

Bank Indonesia supervises the bank capital to set a capital adequacy ratio of banks or capital adequacy ratio (CAR). One of the functions of capital is to protect depositors against losses incurred by the bank. The amount of capital that must be 
provided banks closely related to the bank's asset quality and risk. According to Bank Indonesia Regulation No. 14/18 / PBI / 2012 on the capital adequacy of commercial banks mentioned to rank the risk profile of banks with a minimum of $8 \%$, the second rank to the risk profile of the minimum 9\%, the third rank risk profile by $10 \%$, while the bank with the risk profile of the fourth rank set at $11 \%$ to $14 \%$ of risk-weighted assets.

b. Liquidity risk

Bank is an institution which the business is based on trust, it means customers believe that the funds are deposited in the bank is safe and can be taken at any time. To be believed, then if customers take their funds, banks always provide it. If some customers can not take their funds and spread information on other customers, it is possible there will be violent or taking money together. If this happens, most likely the banks would be bankrupt. Therefore, the bank's liquidity management should be able to guarantee if customers take the funds, the bank is always ready to serve. Once the importance of liquidity, so that Bank Indonesia set a minimum limit of liquidity to be provided by the bank at $5 \%$

c. Financing risk

This risk is caused by the financing provided by Islamic banks are less cautious. The reason is the bank is too easy to provide financing which usually for achieving the target or avoiding the number of idle funds (excess liquidity). As a result, banks had difficulty in gaining back the principal installments and installment margin or profit. In general, credit risk management in Islamic banks is more complicated, especially if the customer fails to pay the principal and profit margins. Because banks charge a penalty was abolished and prohibited restructuring the profit margin becomes subject pinjmanan (Mohammad, 2011). The amount of credit risk will be reflected in the level of nonperformance financing (NPF) of the bank. The higher the level of NPF increasingly risky financing provided. 


\section{Previous Research}

Pratin and Akhyar (2005) found only in third party funds significantly affect financing decision, while the capital risk (CAR), risk financing (NPF) has no effect on financing. Likewise, the liquidity risk (FDR) also had no effect on financing.

Arianti and Muharram (2012) supports the findings Pratin and Akhyar (2005) that only third party fund (funding decision) were significantly and positively influence the financing decision. Capitalrisk (CAR) and financing risk (NPF) does not significantly affect the financing decision.

Sri et.al (2013) conducted a study on three Islamic banks find financing risk (NPF) has a significant effect on the financing, while the third-party funds (funding decision) have no effect on the financing decision. Sri et.al (2013) also found no significant relationship between risk capital (CAR).

Giannini (2013) conducted a study of six Islamic banks find likuidtas risk (FDR) negative and significant effect on mudaraba financing, financing risk (NPF) has no effect, while risk capital positively influences of financing. Prastanto (2013) found teh FDR a positive effect on murabaha financing, while NPF negatively affect murabaha financing.

Findings otherwise performed by Satria and Subegti (2010) who examined the conventional banks, precisely locate influence significantly between capital risk (CAR) to loans. Third party fund and credit risk does not affect of loans.

Pratama (2010) who conducted research on commercial bank in Indonesia in 2005-2009 found the funding decision is proxied by a third party fund significant and positive impact on the loans. He also found the risk of capital (CAR) and credit risk (NPL) significantly and negatively on loans. 


\section{Hypothesis Development}

\section{Effect of funding decision towards financing decision}

Banks are financial intermediaries that distribute funds received from the public (so-called third-party funds) to communities in need in the form of financing or credit. Thus the greater the third party funds the greater the ability of banks to disburse funds in the form of financing. If kebijkanan funding generate funds small fee, then further facilitate financing officer for distributing the funds. Sources of funding from the public on Islamic banks consist of three typeswadia demand deposits, mudaraba savings deposits and mudaraba time deposit.

Research is related to the funding relationship with the financing done by Pratin and Adnan (2005), which examines the factors that affect the financing with one of the variables expected to affect is the third-party funds. The findings do indeed only thirdparty funds that affect the financing. Unfortunately, research Pratin and Adnan (2005) only used a sample of Bank Muamalat Indonesia (BMI) alone, so it can not be used for generalize the national Islamic banking. Research Pratin and Akhyar (2005) supported by Arianti and Muharram (2012) who also found the influence of third party funds (TPF) to finance. While Satrio and Subegti (2010) which examines the factors that affect lending to commercial banks also use third party funds variable as one of the variables that affect lending.

H1: Wadiademand deposit (GWD) ha positive influence on financing decision

H2: Mudarabasaving deposit (TAB) has positive influence on financing decision

H3: Mudarabatime deposit (DEP) has positive influence on financing decision

Banking is an institution in its operations are highly regulated by Bank Indonesia. Therefore, the management of banks should be able to control the risks so as to produce a sound bank. Banking risk decision in this study only uses three types of bank risk, ie the risk of financing the first proxied by the magnitude of the risk of 
financing problems or often referred to as non-performing financing (NPF). NPF magnitude is possible because Islamic banking is very aggressive in financing channel, so that the possibility of financing problems are also high. The greater financing given the higher risk financing unpaid. Both decisions are proxied by risk capital and capital adequacy is measured by the capital adequacy ratio (CAR). Third liquidity risk decision is proxied by the reserve requirement (RR) and financing to deposit ratio (FDR). Reserverequirement is the cash that must be provided by the bank in order to meet withdrawals every-time, good cash in the bank and cash balances at Bank Indonesia. While FDR is the obligation of banks in providing funds in order to meet its financing commitments, the higher the FDR showed the higher financing provided.

Not many researches that examine the factors that affect the financing. Pratin and Akhyar (2005) uses a variable capital ratio (CAR) and the non-performing financing (NPF) as variables that affect the financing, but proved the effect is not significant. Satrio and Subegti (2010) find variables that positively affect bank lending in general is CAR. Arianti and Muharram (2012) also uses a variable risk in the form of capital adequacy ratio (CAR) and the non-performing financing (NPF) as factors that affect the distribution of funding, and find a positive relationship but not significant. Pratama (2010) find a negative influence between CAR and NPL to loans.

H4: Capital risk (CAR) has negative affects the financing decision H5: Liquidity risk (RR) has negativeaffectsthe financing decision H6: Liquidity risk (FDR) has positive influence on financing decision $\mathrm{H7}$ : Financing risk (NPF) has negative affect the financing decision

\section{Research Method}

\section{Population and Sample}

The population in this study is the Islamic banks operating in Indonesia. Until now Islamic banks operating in Indonesia are 11 Islamic banks. Because it is relatively few, then all Islamic banks operating in Indonesia is used as a sample. List the names of Islamic banks as listed in Table 1 below. 
Data of Islamic banks is taken from Bank Indonesia. Since the establishment of Islamic banks is not the same, there are long as Bank Muamalat Indonesia (BMI) were established in 1992 and is also a newly established in 2010, then for the adequacy of the data retrieved quarterly data from 2008 for the founding of the bank before 2008 and taken since the establishment of islamic banks if established after 2008. From the characteristics of the data obtained from the data as much as 177 quarters.

\section{Table 1}

\section{List of Sampel}

\begin{tabular}{cl}
\hline No & \multicolumn{1}{c}{ Bank Name } \\
\hline 1 & PT. Bank Muamalat Indonesia \\
2 & PT. Bank SyariahMandiri \\
3 & PT. Bank Mega Syariah \\
4 & PT. Bank BRI Syariah \\
5 & PT. Bank BukopinSyariah \\
6 & PT. Bank PaninSyariah \\
7 & PT. Bank Victoria Syariah \\
8 & PT. Bank BCA Syariah \\
9 & PT. Bank BJB Syariah \\
10 & PT. Bank BNI Syariah \\
11 & PT. Maybank Indonesia Syariah \\
\hline
\end{tabular}

Source: Islamic Banking Statistik, January 2013 (Bank Indonesia)

\section{Variables and Variable Definitions}

The variables in this study are divided into two categories: first, the dependent variable that is a variable that is influenced by other variables in this case is a financing decision that proxied by three variables: murabaha financing (MUR), of mudaraba financing (MUD), and Musharaka financing (MUS). Second, the dependent variable is affecting other variables. There are two groups of independent variables (1) funding decision is proxied by three variables: wadia deposits (GWD), saving mudaraba (TAB), and deposits mudaraba 
(DEP); (2) Risk of four proxies: capital risk (CAR), liquidity risk (RR and FDR), and risk financing (NPF).

The measurement of each variable, both dependent and independent variables are as follows:

Table 2.

Variable Measurement

\begin{tabular}{|c|c|c|c|}
\hline No & Variabel dan Indikator & Notasi & Pengukuran \\
\hline A & Financing Decisions & & \\
\hline 1 & Murabahah Financing & MUR & $\begin{array}{l}\text { Total Murabaha Financing / } \\
\text { Total Assets }\end{array}$ \\
\hline 2 & MudarabaFinancing & MUD & $\begin{array}{l}\text { Total Mudaraba Financing / } \\
\text { Total Assets }\end{array}$ \\
\hline 3 & MusharakaFinancing & MUS & $\begin{array}{l}\text { Total Musharaka Financing / } \\
\text { Total Assets }\end{array}$ \\
\hline $\mathrm{B}$ & Funding Decisions & & \\
\hline 8 & Murabahah Financing & MUR & $\begin{array}{l}\text { Total Murabaha Financing / } \\
\text { Total Assets }\end{array}$ \\
\hline 9 & Mudaraba Financing & MUD & $\begin{array}{l}\text { Total Mudaraba Financing / } \\
\text { Total Assets }\end{array}$ \\
\hline 10 & Musharaka Financing & MUS & $\begin{array}{l}\text { Total Musharaka Financing / } \\
\text { Total Assets }\end{array}$ \\
\hline $\mathrm{C}$ & Risk & & \\
\hline 4 & $\begin{array}{l}\text { Financing to Deposit } \\
\text { Ratio }\end{array}$ & FDR & $\begin{array}{l}\text { Total Financing / Total Public } \\
\text { Funds }\end{array}$ \\
\hline 5 & Capital Adequacy Ratio & CAR & Owers Capital / ATMR \\
\hline 6 & Liquidity & $\mathrm{RR}$ & $\begin{array}{l}\text { Cash Saldo / Obligation must be } \\
\text { paid }\end{array}$ \\
\hline 7 & Operational Risk & BOPO & $\begin{array}{l}\text { Operational Expense / } \\
\text { Operational Income }\end{array}$ \\
\hline
\end{tabular}

Analytical Tools

To determine the effect of the funding decision and risk financing decision, multiple regressions will be used as analytical tool. Because the decision of financing as the dependent variable 
consists of three variables, then there are three models of the regression equation as follows:

$\mathrm{MUR}=\beta_{0} \mathrm{GWD}+\beta_{1} \mathrm{TAB}+\beta_{3} \mathrm{DEP}+\beta_{4} \mathrm{CAR}+\beta_{5} \mathrm{RR}+\beta_{6} \mathrm{FDR}+\beta_{7} \mathrm{NPF}$
$\mathrm{MUD}=\beta_{0} \mathrm{GWD}+\beta_{1} \mathrm{TAB}+\beta_{3} \mathrm{DEP}+\beta_{4} \mathrm{CAR}+\beta_{5} \mathrm{RR}+\beta_{6} \mathrm{FDR}+\beta_{7} \mathrm{NPF}$
$\mathrm{MUS}=\beta_{0} \mathrm{GWD}+\beta_{1} \mathrm{TAB}+\beta_{3} \mathrm{DEP}+\beta_{4} \mathrm{CAR}+\beta_{5} \mathrm{RR}+\beta_{6} \mathrm{FDR}+\beta_{7} \mathrm{NPF}$

Where:

MUR = murabahah financing

MUD = mudarabafinancing

MUS = musharakafinancing

GWD = wadia demand deposit

$\mathrm{TAB}=$ mudaraba savingdeposit

DEP $=$ mudarabatime deposit

$\mathrm{CAR}=$ capital adequacy ratio

$\mathrm{RR} \quad=$ Reserve requirement

FDR = financing to deposit ratio

$\mathrm{NPF}=$ non performing financing

\section{Result and Discussion}

From the data of eleven Islamic banks operating in Indonesia and processed using SPSS version 17.00, the results are as follows:

Statistics Descriptive

Statitistics description shows the mean, median, maximum and minimum of the variables in the study as in Table 3 below: 
Table 3

Descriptive statistic

\begin{tabular}{llllll}
\hline & Mean & Median & Maximum & Minimum & Std. Dev. \\
\hline MUR & 71.38 & 72.27 & 100.00 & 12.93 & 19.28 \\
MUD & 9.66 & 7.53 & 41.07 & 0.00 & 19.28 \\
MUS & 16.20 & 14.44 & 83.41 & 0.00 & 12.36 \\
GWD & 10.64 & 8.91 & 51.66 & 1.02 & 8.02 \\
TAB & 19.38 & 15.50 & 42.67 & 0.93 & 12.81 \\
DEP & 69.98 & 74.30 & 97.77 & 39.59 & 15.89 \\
CAR & 33.58 & 17.04 & 91.23 & 9.04 & 39.03 \\
RR & 6.93 & 5.27 & 26.55 & 5.01 & 3.97 \\
FDR & 97.60 & 91.87 & 205.31 & 9.04 & 39.03 \\
NPF & 3.32 & 2.96 & 8.46 & 0.00 & 6.41
\end{tabular}

Source: Processed from the Bankss financial statements

The table above shows that the amount of financing is dominated by murabaha financing which reached an average of $71.38 \%$, even some banks are financing in the form of murabaha financing. Musharaka financing is an average 9.66\%, while the average 16:20\%. From these data indicate more Islamic banks provide financing on the most secure financing.

In terms of funding decision, funding sources most widely form of mudarabatime deposits with an average reached $69.98 \%$, the average mudarabasavings deposit 19:38\%, and wadiademand deposits averaged only $10.64 \%$. This condition shows that Islamic banks still rely on sources of funding that the cost of the most expensive, because mudarabatime deposits is a source of funds that provide the profit sharing with the highest ratio compared to other funding sources.

Capitalrisk that measured by the capital adequacy ratio (CAR) is still relatively high because the average CAR of $33.58 \%$ with a maximum of $91.23 \%$, whereas the rules are a maximum of $12 \%$. Liquidity risk is measured by the minimum reserve requirement (RR) the regulatory minimum of 5\% is good enough for the average 
of $6.93 \%$, while liquidity as measured by financing ti deposit ratio (FDR) showed an average of 97.60 has been cuku either because FDR between $90 \%-110 \%$, but there are still very high bank FDR which amounted to $205.31 \%$. Financing risk as measured by the non-performing financing (NPF) has an average of $3.31 \%$. This figure shows that the NPF Islamic banking is still good because it does not exceed the limit of 5\% maximum, although there is a bank that the NPF at 8:46\%.

\section{Results and Discussion}

From the results of data processing using eviews program, we can see the effect of the funding decision (GWD, TAB and DEP) and the influence of risk (CAR, RR, FDR, and NPF) to the financing decision (MUR, MUD and MUS) can be seen in the table below

Table 4

Effect of Funding Decision and Risk On Financing Decision

\begin{tabular}{lllllll}
\hline & \multicolumn{3}{c}{ MUR } & \multicolumn{2}{c}{ MUD } & \multicolumn{2}{c}{ MUS } \\
& Coefficient & Prob & Coefficient & Prob & Coefficient & Prob \\
\hline GWD & 0.228751 & 0.0000 & -2.387611 & 0.00000 & -2.137318 & 0.0000 \\
TAB & 0.175166 & 0.0009 & 2.052008 & 0.00000 & 1.825558 & 0.0000 \\
DEP & 0.604099 & 0.0000 & 1.469495 & 0.00490 & 1.462768 & 0.0000 \\
CAR & -3.147929 & 0.0000 & -4.221988 & 0.00010 & -5.984325 & 0.0000 \\
RR & -8.729516 & 0.0011 & -20.04765 & 0.05900 & -16.75893 & 0.0022 \\
FDR & -0.241761 & 0.2665 & -3.415195 & 0.0001 & -4.222408 & 0.0000 \\
NPF & 1.713906 & 0.1720 & 4.128095 & 0.40970 & 3.098202 & 0.2261 \\
\hline
\end{tabular}

a. Effect of funding decision towards financing decision

Third party funding sources such as wadia demand deposit (GWD) significant and positive impact on murabaha financing, because probalitasnya value of 0.000 is smaller than the significance level of 0.05 , but the negative effect on mudaraba financing and musharaka financing. Mudaraba avingsdeposit significant and positive impact on all of a type of financing that is characterized by the probabiltasnya value smaller than 
the significance level. Similarly, the mudaraba time deposits are also significant and positive effect on all financing decision.

Wadia demand deposit has positive effect on murabaha financing means that funds derived from wadia deposits only be used for financing at the low risk, because wadiademand deposits can be taken at any time. Mudaraba savings deposit and mudharaba time deposit a significant effect on all financing, this indicates that the funds came from mudarabasavings deposits and mudaraba time deposit used to fund all types of financing. Of the three types of funds, mudaraba time deposits still have largest portion. Time deposits are kind of public funds that the most expensive funds, so that the greater the portion of mudarabatime deposits show more expensive funds distributed to the public.

The results of this study support the findings Pratin and Akhyar (2005), Ariyanti and Muharram (2012) who found a positive effect of third party funds to finance a given Islamic banks. Similarly, Pratama (2010), which examines the conventional banks have also found a significant and positive effect of third-party funds to loans. While Satrio and Subegti (2010) found the opposite result that the fund does not affect the third-party on loans.

b. Influence on the risk of financing decision

Capitalrisk (CAR) significant and negatively impact on all financing is characterized by the probability that the value is smaller than the significance level of 0.05 . This indicates the greater the CAR will further lower the amount of financing provided. These results are consistent with the hypothesis, because the higher CAR showed less efficient capital management. Indeed, the health of the banks CAR high indicates a healthy bank, but in terms, high CAR indicate banks are less efficient, so can reduce profitability. Satrio and Subegti (2010) and Pratama (2010), which examines the conventional banks also found CAR negatively affect on loan. While Pratin and Akhyar (2005), Ariyanti and Muharram (2012) who studied Islamic banks find CAR does not significantly affect on the financing.

Liquidity risk is measured by the reserve requirement (RR) is also significant and negative influential of all financing for smaller 
probability value 0:05. FDR shows a comparison between financing with public funds influence on murabaha financing is not significant because the value is greater than the probability 0.2665 significance level of 0.05 but on mudaraba financing and Musharaka financing a significant and negative effect, it's mean that the higher FDR both financings tend to go down. This suggests a more Islamic banks focus murabaha financing impositions which incidentally is financing without risk. Sutrisno and Basuki (2014) found murabaha financing significant and dominant affect on profitability. Research findings are supported by Prastanto (2013) who found FDR positive effect on murabaha financing. Support also from the findings Giannini (2013) who found a negative influence on the FDR of financing.

Financing risk as measured by non-performing financing (NPF) has a probability value is greater than the 0.05 significance level, meaning that NPF did not have an influence on all financing. Thus the rise and fall of NPF does not affect the size of all types of financing provided. These findings indicate that Islamic banks do not dare to take the risk, because the risk does not affect the size of the financing. These results are supported by almost all research in Islamic banks. Pratin and Akhyar (2005), Arianti and Muharram (2012), Giannini (2013) also found NPF no significant effect on the financing. Satrio and Subegti (2010) which examines the conventional banks also found the same thing, but Pratama (2010) find the NPL a negative effect on loans

\section{Conclusion}

From the results of the analysis of data and discussion can be concluded that the funding decision significantly influences on the financing decision. The biggest source of funding is mudaraba time deposits. Wadia demand deposit only given for the murabaha financing which only has a lowrisk, because of its influence value of mudaraba and Musharaka financing is negative. Capital risk (CAR) significantly influence and negative, but this is simply because the higher CAR showed less efficient use of capital. Similarly, the liquidity that measured by reserve requirement is significant and negative 
effect, meaning that the higher the greater reserve requirement show that funds banks are idle because it is not used for financing. While liquidity measured by FDR did not significantly affect the murabaha financing decision, but a significant and negative effect on profit and Musharaka financing. It shows that Islamic banks do not dare to give financing risk. The financing risk is measured by the NPF showed no significant effect, so little or big financing risk does not affect the amount of financing.

\section{References}

Antonio, Muhammad Syafi'i. 2001. Bank Syariah: Dari Teorike Praktik, Gema Insani Press, Jakaarta

Arianti N. P, Wuri and Harjum Muharam. 2012. Analisis Pengaruh Dana Pihak Ketiga (DPK), Capital Adequacy Ratio (CAR), Non Performance Financing (NPF), dan Return on Asset (ROA) terhadap Pembiayaan pada Perbankan Syariah, Working Paper, eprint.undip.ac.id/32445/jurnal_wuri

Bank Indonesia. 2013. StatistikPerbankanSyariah - Januari 2013, Jakarta

Giannani, Nur Gilang. 2013. Faktor-Faktor yang Mempengaruhi Pembiayaan Mudarabah pada Bank Umum Syariah di Inodensia, Accounting Analys Journal, Vol 2(1)

Hidayat, Sutan Emir. 2008. Tujuan dan Arah Keuangan Islam, Opini di Koran Republika pada tanggal 2 Agustus 2008

Muhammad. 2011. Manajemen Bank Syariah, UPP AMP YKPN, Yogyakarta

Peraturan Bank Indonesia Nomor 13/23/PBI/2011 Tentang Penerapan Manajemen Risiko Bagi Bank Umum Syariah Dan Unit Usaha Syariah

Pratama, Billy Arma. 2010. Analisis Faktor - Faktor Yang Mempengaruhi Kebijakan Penyaluran Kredit Perbankan (Studi pada Bank Umum di Indonesia Periode Tahun 2005 - 2009), Working Paper

Pratin and Akhyar Adnan. 2005. Analisis Hubungan Simpanan, Modal Sendiri, NPL, Prosentase Bagi Hasil dan Markup 
Keuntungan terhadap Pembiayaan pada Perbankan Syariah: Studi Kasus pada Bank Muamalat Indonesia (BMI), Jurnal Sinergi: Kajian Bisnisdan Manajemen, EdisiKhusus, 35-52

Prastanto. 2013. Faktor yang Mempengaruhi Pembiayaan Murabahah pada Bank Umum Syariah di Inodensia, Accounting Analys Journal, Vol 2(1)

Satrio, Dias and Rangga Bagus Subegti. 2010. Determinasi Penyaluran Kredit Bank Umum di Indonesia Periode 2006-2009, Jurnal Keuangan dan Perbankan, 14(3), 425-424

Siamat, Dahlan. 2005. Manajemen Lembaga Keuangan: Kebijakan Moneter dan Perbankan, Lembagai Penerbit Fakultas Ekonomi Universitas Indonesia, Jakarta

Sri, Anastya., Ratna Anggraini, Etty Gureb dan Nuramalia Hasanah. 2013. The Influence of Third Party Fund, CAR, NPF, and ROA Against the Financing of General Syariah-Based bank in Indonesia, International Conference on Business, Economics, and Accounting, Bangkok, Thailand

Sudarsono, Heri. 2003. Bank dan Lembaga Keuangan Syariah, Penerbit Ekonisia, Yogyakarta

Sumitro, Warkam. 2002. Asas- asas Perbankan Islam dan Lembagalembaga Terkait, Jakarta: Raja Grafindo.

Surat Edaran Bank Indonesia: SE No.5/21/DPNP tahun 2003 tentang Penerapan Manajemen Risikobagi Bank Umum

Surat Edaran Bank Indonesia, SE No.13/23/DPNP tahun 2011 tentang Perubahan SE No. 5/21/DNDP/ 2003 perihal Penerapan ManajemenRisikobagi Bank Umum

Sutrisno an R. Agus Basuki. 2014. Pengaruh Kebijakan anajemendan embiayaan terhadap Kinerja bank Syariah: Kajian Empiris pada Bank Syariah di Indonesia, Jurnal Ekonomi dan Bisnis Islam (EKBISI), VIII (2)

Yahya, Rizal., dkk. 2009. Akuntansi Perbankan Syariah, Jakarta: Salemba Empat.

Undang-undang No. 21 tahun 2008 tentangPerbankanSyariah Undang-undang No. 7 tahun 1992 tentang Perbankan 